\title{
Infección por herpes virus y test de Tzanck
}

\section{Herpes virus infection and Tzanck test}

\author{
Juan Sebastián Espinosa-Serna, Jacqueline Mugnier • Bogotá, D.C. (Colombia)
}

DOI: https://doi.org/10.36104/amc.2019.1313

Mujer de 65 años con leucemia linfoide crónica que presentó lesiones tipo vesículas, pústulas y costras con extensión a dorso, cara, tórax y abdomen (Figuras 1 y 2), considerando pustulosis exantemática aguda generalizada vs varicela zoster iniciando manejo con aciclovir y estudio con PCR para varicela zoster, por demora de PCR y el riesgo de exposición a aciclovir se solicitó test de Tzanck, confirmando infección por herpes virus (Figura 3), atribuido a varicela zoster completando esquema de aciclovir, finalmente se recibe reporte de PCR positivo para éste.

El Test de Tzanck un test rápido, simple y no costoso para examinar las lesiones vesiculares y confirmar infección por herpes virus con la limitación de no diferenciar infección por herpes simplex virus 1,2 o 3 , es en un test con buen rendimiento operativo (sensibilidad de 40-80\% y especificidad hasta $100 \%$ ) ante la duda diagnóstica de infección por herpes virus.

\section{Referencias}

1. Wanat KA, Dominguez AR, Carter Z,et al. Bedside diagnostics in dermatology: Viral, bacterial, and fungal infections. J Am Acad Dermatol. 2017 Aug;77(2):197-218

2. Ozcan A, Senol M, Saglam H,et al. Comparison of the Tzanck test and polymerase chain reaction in the diagnosis of cutaneous herpes simplex and varicella zoster virus infections. Int J Dermatol. 2007 Nov;46(11):1177-9.

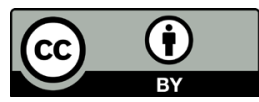

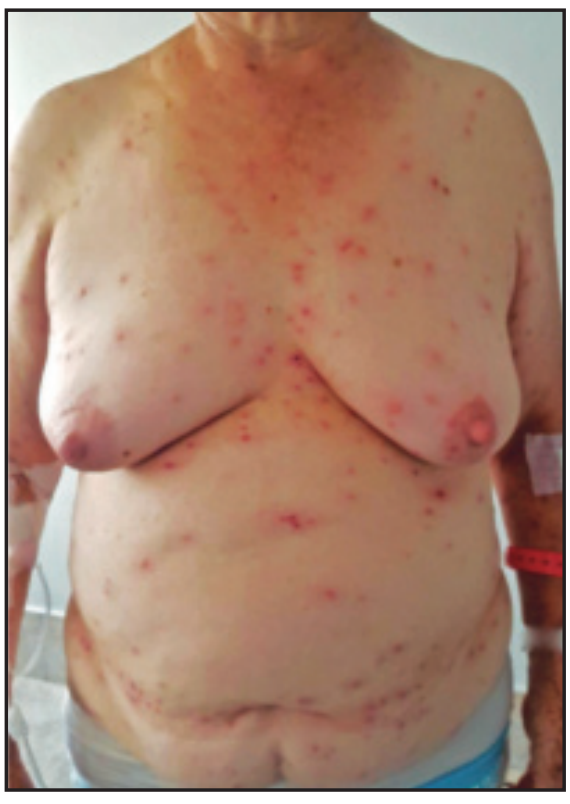

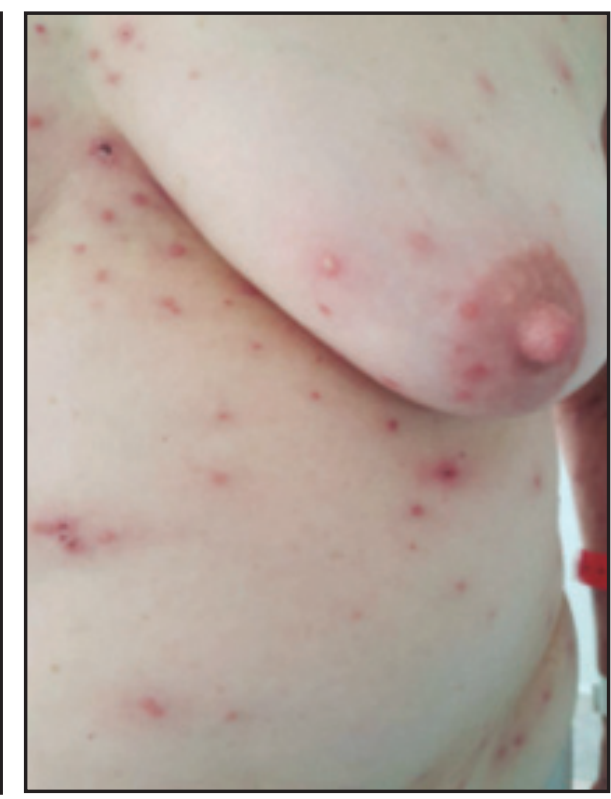

Figuras 1 y 2. Múltiples vesículas eritematosas, con algunas pústulas y costras de distribución generalizada.

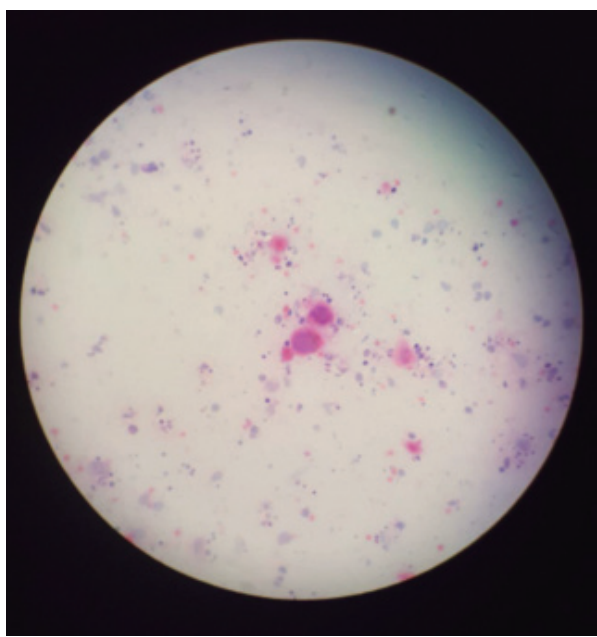

Figura 3. Test de Tzanck: H-E 40X, células epiteliales con multinucleación y núcleos de aspecto borroso con moldeamiento nuclear.

Dr. Juan Sebastián Espinosa-Serna: Médico y Cirujano Egresado de la Universidad del Rosario. Residente de 3er. año de Medicina Interna, Universidad del Rosario, Fundación Cardioinfantil; Dra. Jacqueline Mugnier: Patóloga de la Fundación Cardioinfantil. Bogotá, D.C. (Colombia). 